\title{
Cold enzymatic bleaching of fluid whey
}

\author{
R. E. Campbell and M. A. Drake ${ }^{1}$ \\ Department of Food, Bioprocessing and Nutrition Sciences, Southeast Dairy Foods Research Center, North Carolina State University, \\ Raleigh 27695
}

\section{ABSTRACT}

Chemical bleaching of fluid whey and retentate with hydrogen peroxide (HP) alone requires high concentrations (100-500 mg of $\mathrm{HP} / \mathrm{kg}$ ) and recent studies have demonstrated that off-flavors are generated during chemical bleaching that carry through to spray-dried whey proteins. Bleaching of fluid whey and retentate with enzymes such as naturally present lactoperoxidase or an exogenous commercial peroxidase (EP) at cold temperatures $\left(4^{\circ} \mathrm{C}\right)$ may be a viable alternative to traditional chemical bleaching of whey. The objective of this study was to determine the optimum level of HP for enzymatic bleaching (both lactoperoxidase and $\mathrm{EP}$ ) at $4^{\circ} \mathrm{C}$ and to compare bleaching efficacy and sensory characteristics to HP chemical bleaching at $4^{\circ} \mathrm{C}$. Selected treatments were subsequently applied for whey protein concentrate with $80 \%$ protein (WPC80) manufacture. Fluid Cheddar whey and retentate $(80 \%$ protein) were manufactured in triplicate from pasteurized whole milk. The optimum concentration of HP (0 to $250 \mathrm{mg} / \mathrm{kg}$ ) to activate enzymatic bleaching at $4^{\circ} \mathrm{C}$ was determined by quantifying the loss of norbixin. In subsequent experiments, bleaching efficacy, descriptive sensory analysis, and volatile compounds were monitored at selected time points. A control with no bleaching was also evaluated. Enzymatic bleaching of fluid whey and retentate at $4^{\circ} \mathrm{C}$ resulted in faster bleaching and higher bleaching efficacy (color loss) than bleaching with HP alone at $250 \mathrm{mg} / \mathrm{kg}$. Due to concentrated levels of naturally present lactoperoxidase, retentate bleached to completion ( $>80 \%$ norbixin destruction in $30 \mathrm{~min})$ faster than fluid whey at $4^{\circ} \mathrm{C}(>80 \%$ norbixin destruction in $12 \mathrm{~h}$ ). In fluid whey, the addition of EP decreased bleaching time. Spray-dried WPC80 from bleached wheys, regardless of bleaching treatment, were characterized by a lack of sweet aromatic and buttery flavors, and the presence of cardboard flavor concurrent with higher relative abundance of 1-octen3 -ol and 1-octen-3-one. Among enzymatically bleached WPC80, lactoperoxidase-bleached WPC80 contained

Received February 22, 2013.

Accepted September 3, 2013.

${ }^{1}$ Corresponding author: maryanne_drake@ncsu.edu higher relative abundance of 2,3-octadienone, 2-pentyl furan, and hexanal than those bleached with added EP. Bleach times, bleaching efficacy, and flavor results suggest that enzymatic bleaching may be a viable and desirable alternative to HP bleaching of fluid whey or retentate.

Key words: whey, lactoperoxidase, flavor, bleach

\section{INTRODUCTION}

Whey is a by-product of cheese manufacture and is often further processed into value-added products, such as whey protein concentrate 34 or $80 \%$ or whey protein isolate (>90\% protein). Typical whey processing steps include fat separation, pasteurization, bleaching, UF, diafiltration, and spray drying. The flavor of fluid whey carries through into the final spray-dried products (Croissant et al., 2009), and consumers and product manufacturers demand that dried whey ingredients be colorless with a bland flavor (Kang et al., 2010).

The manufacture of Cheddar cheese has continued to increase and Cheddar whey is one of the main sources of cheese whey. Norbixin, a natural orange-colored carotenoid, is added to Cheddar cheese milk to impart the desired orange color and a portion of the norbixin is retained in the fluid whey (Kang et al., 2010) and must be bleached. Off-flavors in dried whey proteins associated with bleaching, either with benzoyl peroxide or hydrogen peroxide (HP), have been well documented in the literature (Croissant et al., 2009; Listiyani et al., 2011, 2012; Jervis et al., 2012). Due to the increased demand for bland, colorless whey ingredients and international concerns with the use of benzoyl peroxide and increasing concerns with HP, chemical bleaching alternatives are desirable (Campbell et al., 2012; Kang et al., 2012). Campbell et al. (2012) recently demonstrated that as little as $10 \mathrm{mg}$ of $\mathrm{HP} / \mathrm{kg}$ was sufficient for greater than $80 \%$ norbixin destruction by lactoperoxidase $(\mathbf{L P})$ in fluid whey at $35^{\circ} \mathrm{C}$. Enzymatic bleaching, either using the native LP system or by adding an exogenous peroxidase (EP) has yet to be fully explored.

Lactoperoxidase, a native enzyme found in milk, is often used to increase storage stability and reduce the loss of fresh milk quality due to microbial spoilage. Lactoperoxidase is a member of the peroxidase family and 
when its activators thiocyanate and HP are present, hypothiocyanate, a potent antimicrobial, is produced (Reiter and Harnulv, 1982). In addition to milk preservation, the LP system can be used to bleach whey (Bottomley et al., 1989; Campbell et al., 2012). The strong oxidizing capacity of hypothiocyanate results in the destruction of carotenoid conjugation and subsequent color loss of norbixin in cheese whey. Using the LP system to bleach whey can be highly variable, as levels of LP can vary depending on the lactation cycle of the cow, season, feeding regimen, and breed (Kussendrager and van Hooijdonk, 2000). Similar to LP, thiocyanate concentration in milk and whey can vary widely due to feeding regimen (Seifu et al., 2005). The third component of the LP system, HP, is not normally detected in raw milk and is typically added exogenously. Hydrogen peroxide can be generated endogenously by bacteria, although amounts sufficient to activate the LP system may not be generated (Seifu et al., 2005). Depending on the milk, any 1 of the 3 components that make up the LP system could limit LP activity.

To facilitate enzymatic whey bleaching, a commercial $\mathrm{EP}$ is available and can be added to fluid whey product in small quantities to help achieve desired and consistent bleaching efficacy. This enzyme, MaxiBright (MB), is derived from a mushroom, Marasmius scorodonius (Zorn et al., 2003). Very little is known about the enzyme mechanism compared with that of LP; however, it is known that both of these enzymes require similar amounts of HP to activate their respective systems (Bottomley et al., 1989; Zorn et al., 2003). Since the original patent was filed in 2006, several studies have addressed the bleaching capacity of MB on $\beta$-carotene in model systems (Scheibner et al., 2008; Pühse et al., 2009; Zelena et al., 2009); however, the bleaching efficacy and subsequent effects on the flavor of MB in conjunction with the natural LP system in fluid whey has yet to be investigated. Studies have demonstrated that chemical bleaching at colder temperatures $\left(<10^{\circ} \mathrm{C}\right)$ results in less lipid oxidation (Listiyani et al., 2011). Additionally, colder temperatures enhance membrane stability, microbial quality, and protein integrity. As such, cold bleaching is an attractive process. The objective of this study was to optimize enzymatic bleaching of whey and retentates with both LP and EP at $4^{\circ} \mathrm{C}$ and to evaluate their subsequent effects on the flavor of whey protein concentrate with $80 \%$ protein (WPC80).

\section{MATERIALS AND METHODS}

\section{Experimental Design Overview}

The study had 2 experimental components: liquid whey and retentate trials and the manufacture of
WPC80. Optimum HP levels to activate the LP and EP systems were first determined. Liquid whey and retentate trials were then conducted to determine optimum bleach times at $4^{\circ} \mathrm{C}$. The liquid whey treatments with the most bleaching and the fastest bleaching times were then selected for WPC80 manufacture. All treatments within each trial were made from the same lot of milk. All experiments were conducted in triplicate.

\section{Production of Liquid Whey}

Cheddar whey was manufactured from HTST (15 s at $\left.72^{\circ} \mathrm{C}\right)$ pasteurized whole milk $(720 \mathrm{~kg} / \mathrm{h}$; model T4 RGS-16/2; SPX Flow Technology, Greensboro, NC). The milk was then cooled to $31^{\circ} \mathrm{C}$ and transferred to a cheese vat (Kusel Equipment Co., Watertown, WI). Colored Cheddar whey manufacture proceeded as described by Campbell et al. (2011). The whey was drained from the curds at $\mathrm{pH} 6.3$ and a sieve was used to remove any remaining particles. The whey was immediately processed with a hot bowl cream separator (model SI600E; Agrilac, Miami, FL) to reduce the fat content. Fat-separated, fluid whey was then HTST pasteurized as described previously. Whey was cooled to $4^{\circ} \mathrm{C}$ before bleaching experiments.

\section{Production of Retentate}

Fat-separated, pasteurized fluid whey was transferred into a 102-L stainless vat (Fermenator; Blichmann Engineering, Lafayette, IN) equipped with a coil heater (1.3-cm outer diameter; PAC Stainless Ltd., Seattle, WA) and heated to $50^{\circ} \mathrm{C}$ while recirculating using a peristaltic pump (model 77410-10; Millipore Inc., Billerica, MA). Once the desired temperature was reached, UF commenced. The UF system (model Pellicon 2; Millipore Inc.) was equipped with 10 polyethersulfone cartridge membrane filters (model P2B010V05; 10-kDa nominal separation cutoffs, $0.5 \mathrm{~m}^{2}$ surface area; Millipore Inc.). Each sample was run through a peristaltic pump (model 77410-10; Millipore Inc.) and the UF assembly using silicone tubing (model 96440-73; Millipore Inc.) that was connected to the vat. Pumps, pump heads, and tubing were all obtained from ColePalmer (Vernon Hills, IL). Ultrafiltration and diafiltration continued until the retentate reached $80 \%$ protein content on a dry basis (wt/wt), confirmed by a Sprint rapid protein analyzer (CEM Corp., Matthews, NC). Retentates were then collected and cooled to $4^{\circ} \mathrm{C}$ before bleaching experiments.

\section{Activation of the LP or EP System}

The optimum level of HP to activate the LP or EP system was determined by adding $0,5,10,15,20,25$, 
$30,35,40,45,50,55,60,65,70,75,80,85,90,95,100$, 150,200 , or $250 \mathrm{mg} / \mathrm{kg}$ HP to pasteurized fat-separated liquid Cheddar whey or retentate $(80 \%$ protein on a dry basis; $10 \%$ solids). Bleaching was then carried out as described below. The concentration of HP that resulted in the most bleaching $(10 \mathrm{mg} / \mathrm{kg}$ in fluid whey and 15 $\mathrm{mg} / \mathrm{kg}$ in retentate, according to norbixin destruction determined via HPLC) was selected for further trials.

\section{Optimum Bleaching Time}

Liquid whey or retentate $[10 \%$ solids (wt/vol); $80 \%$ protein on a dry basis (wt/wt)] was placed in amber glass jars in an ice bath and allowed to equilibrate to $4^{\circ} \mathrm{C}$. To activate the LP system, $10 \mathrm{mg} / \mathrm{kg}$ of HP (liquid whey) or $15 \mathrm{mg} / \mathrm{kg}$ of HP [retentate; $35 \%$ (wt/ vol); Nelson Jameson Inc., Marshfield, WI] was added and allowed to bleach in an ice bath with gentle agitation. To activate the EP system, 2 dairy bleaching units (DBLU) of MB (DSM, Delft, the Netherlands) was added to the liquid whey or retentate and agitated gently. To that, 10 or $15 \mathrm{mg}$ of $\mathrm{HP} / \mathrm{kg}$ was added and allowed to bleach in the ice bath with gentle agitation. Aliquots of samples were removed at appropriate time points (fluid whey: $0,0.5,1,2,4,6$, and $24 \mathrm{~h}$; retentate: $0,3,5,7,10,15,20,30,40$, and $50 \mathrm{~min}$, and $1,2,4$, 6 , and $24 \mathrm{~h}$ ). Peroxide test strips (EMD Chemicals, VWR International LLC, West Chester, PA) were used to determine if any HP remained after the bleaching treatment. To consume the remaining HP to stop peroxidase activity, catalase (FoodPro CAT; Danisco, New Century, NJ) was added at a rate of $20 \mathrm{mg} / \mathrm{kg}$. Measurements, including norbixin, volatile compound analyses, and descriptive analysis were performed immediately.

\section{Production of WPC80}

Industrially, due to manufacturing constraints, bleaching most frequently occurs at the fluid whey level. We also observed differences in the amount of time required for LP and EP bleaching in fluid whey. For these reasons, liquid whey was selected as the bleaching point for WPC80 trials. Treatments were selected based on current industrial practices and from the previous liquid whey trials to achieve maximum bleaching at $4^{\circ} \mathrm{C}$ [LP: $10 \mathrm{mg}$ of $\mathrm{HP} / \mathrm{kg}$ for $12 \mathrm{~h}$, EP: 2 DBLU of $\mathrm{MB}$ and $10 \mathrm{mg}$ of $\mathrm{HP} / \mathrm{kg}$ for $1 \mathrm{~h}$, HP: $250 \mathrm{mg} / \mathrm{kg}$ for $12 \mathrm{~h}$, and control (no bleaching) for $12 \mathrm{~h}$ at $4^{\circ} \mathrm{C}$ ] for manufacture of WPC80. Colored fat-separated cheese whey was freshly manufactured as previously described. The pasteurized separated whey was placed in sanitized 38-L milk cans at $4^{\circ} \mathrm{C}$. Two of 3 treatments were administered immediately: LP $[10 \mathrm{mg} / \mathrm{kg}$ of HP $(35 \%$ wt/vol; Nelson Jameson Inc.)] or HP (250 mg/kg) and allowed to bleach overnight. The following morning, the last treatment (EP) was administered (2 DBLU of MB and $10 \mathrm{mg}$ of $\mathrm{HP} / \mathrm{kg}$ ) and allowed to bleach for $1 \mathrm{~h}$. If any HP remained after treatment, catalase was added at a rate of $20 \mathrm{mg} / \mathrm{kg}$ (FoodPro CAT; Danisco) to consume the remaining HP and stop peroxidase activity.

Bleached wheys were transferred into a 102-L stainless vat (Fermenator; Blichmann Engineering) equipped with a coil heater (1.3-cm outer diameter; PAC Stainless Ltd.) and heated to $50^{\circ} \mathrm{C}$ while recirculating using a peristaltic pump (model 77410-10; Millipore Inc.). Once the desired temperature was reached, UF commenced. The UF system (model Pellicon 2, Millipore Inc.) was equipped with 5 polyethersulfone cartridge membrane filters (model P2B010V05; 10-kDa nominal separation cutoffs, $0.5 \mathrm{~m}^{2}$ surface area; Millipore Inc.). Each sample was run through a peristaltic pump (model 77410-10; Millipore Inc.) and the UF assembly using silicone tubing (model 96440-73; Millipore Inc.) that was connected to the vat. Pumps, pump heads, and tubing were all obtained from Cole-Palmer. Ultrafiltration and diafiltration continued until the retentate reached $80 \%$ protein content on a dry basis (wt/wt), confirmed by a Sprint rapid protein analyzer (CEM Corp.). Retentates were then collected and spray dried (model Lab 1; Anhydro Inc., Søborg, Denmark). The inlet temperature was $200^{\circ} \mathrm{C}$ and the outlet temperature was $90^{\circ} \mathrm{C}$. Total spray-drying time was about 1 h. The powder was collected and stored in Mylar bags at $-80^{\circ} \mathrm{C}$ following production. All treatments were manufactured from the same lot of milk and the experiment was conducted in triplicate.

\section{Compositional Analysis}

Total solids of defatted liquid whey and WPC80 were determined by air-oven drying (AOAC International, 2000; method number 990.20; 33.2.44). In powdered WPC80, fat was quantified by the Mojonnier method (AOAC International, 2000; method numbers 932.06 and 989.05). In defatted liquid wheys, fat was quantified using the CEM Smart Trac rapid fat analyzer (CEM Corp.). Protein was determined using the Kjeldahl method in powdered whey proteins (AOAC International, 2000; method number 991.20; 33.2.11) or using the Sprint Rapid Protein Analyzer (CEM Corp.) if the whey was liquid. Mineral analysis (phosphorus, calcium, magnesium, potassium, sulfur, sodium, and iron) was done by the North Carolina State University Analytical Services Laboratory (Raleigh, NC) using a standard dry ash method with inductively coupled plasma optical emission spectroscopy (Lloyd et al., 2009). All samples were measured in duplicate. 


\section{Hunter $L{ }^{*} a{ }^{*} b^{*}$ Values}

The WPC80 were measured in both powder form $(10 \mathrm{~g})$ and liquid form [10 mL of $10 \%$ (wt/vol) solution]. Ten milliliters of the sample [rehydrated at $10 \%$ (wt/vol) solids, if necessary] was placed into the bottom of a $60 \times 15-\mathrm{mm}$ polystyrene Petri dish (Becton Dickinson, Franklin Lakes, NJ). The color of WPC80 was measured using a Minolta Chroma meter (CR-410; Konica Minolta Sensing Americas Inc., Ramsey, NJ). Each sample was measured in duplicate. Before measurements were taken, a factory-supplied calibration plate was used to calibrate the instrument. The Hunter CIE $\mathrm{L}^{*} \mathrm{a}^{*} \mathrm{~b}^{*}$ color scale (where $\mathrm{L}^{*}$ is the lightness of the color, $\mathrm{a}^{*}$ is its position between red/magenta and green, and $b^{*}$ is its position between yellow and blue) was used. Reflectance values were taken with a white calibration plate as the background.

\section{Norbixin Extraction and Quantification}

Norbixin is the primary carotenoid in water-soluble annatto extracts and was extracted and measured to determine percentage annatto destruction and bleaching efficacy (Kang et al., 2010). Norbixin was extracted and quantified using HPLC. To extract defatted fluid wheys, $200 \mu \mathrm{L}$ was placed into a $2-\mathrm{mL}$ microcentrifuge tube (VWR International LLC). To this, $800 \mu \mathrm{L}$ of dilution solution $[80 \%$ acetonitrile $/ 20 \%$ water with $0.1 \%$ (wt/vol) formic acid; EMD Chemicals, VWR International LLC] was added. The solution was vortexed and centrifuged at 14,000 $\times g$ (Microfuge 18 centrifuge; Beckman Coulter, Brea, CA). The supernatant was removed and placed into vials for quantification by HPLC. To extract powders, samples were first reconstituted to $10 \%$ solids using deionized water. Then, 100 $\mu \mathrm{L}$ of sample was placed into a $2-\mathrm{mL}$ microcentrifuge tube. To this, $900 \mu \mathrm{L}$ of dilution solution was added and the sample was vortexed and centrifuged as previously described. The supernatant was removed and placed into vials for quantification by HPLC. The extraction procedure and measurements were performed with premium full-spectrum F885 flat sheet filters covering all lights (Ergomart, Dallas, TX) to minimize norbixin isomerization and degradation (Mercadante, 2008).

Quantification was conducted using HPLC (Waters 1525 Binary Pump; Waters Corp., Milford, MA). Isocratic mobile phase $[70 \%$ acetonitrile $/ 30 \%$ water with $0.1 \%$ (wt/vol) formic acid; EMD Chemicals, VWR International LLC] was used at a flow rate of $1 \mathrm{~mL} / \mathrm{min}$ pumped through a binary pump (Waters 1525; Waters Corp.). Fifty microliters of the sample was injected (Waters 2707 Autosampler; Waters Corp.) onto the column (Phenomenex Kinetex 2.6- $\mu \mathrm{m}$ particle size, 10- cm length, 4.6-mm i.d., 100-A pore size; Phenomenex Inc., Torrance, CA), which was heated to $40^{\circ} \mathrm{C}$. The injector temperature was set to $4^{\circ} \mathrm{C}$. The sample was sent through a photodiode array detector (Waters 2998; Waters Corp.). A standard curve was created by rehydrating norbixin powder [45\% (wt/vol); Chr. Hansen, Milwaukee, WI] in 2.5\% (wt/vol) potassium hydroxide (BDH; VWR International LLC) and then diluting in mobile phase. The maxima used for calculation was 482 nm. Norbixin concentration was calculated by TS and correction for dilution during the extraction and solidphase extraction processes.

\section{Descriptive Sensory Analysis}

Sensory analysis was conducted on defatted fluid wheys, retentates, and rehydrated WPC80 (10\% wt/ vol) using a trained descriptive sensory panel and an established dairy flavor language (Drake et al., 2003, 2009). Panelists $(\mathrm{n}=8)$ each had more than $150 \mathrm{~h}$ of previous experience with the sensory analysis of fluid and dried whey products using the Spectrum descriptive analysis method (Meilgaard et al., 2007). All sensory testing was conducted in accordance with the North Carolina State University Institutional Review Board for Human Subjects guidelines.

Defatted fluid wheys, retentates, or reconstituted WPC 80 [10\% solids (wt/vol)] were evaluated by placing $30 \mathrm{~mL}$ in 3-digit-coded 60-mL lidded cups (Solo Cup Co., Champaign, IL). Preparations were conducted with overhead lights off to avoid exposure to light. Samples were evaluated by each panelist in duplicate. Sensory data were collected on paper ballots or using Compusense five (release 4.8; Compusense Inc., Guelph, ON, Canada).

\section{GC-MS}

Selected volatile compounds in defatted fluid wheys and WPC80 powder were extracted by solid-phase microextraction (SPME) using selective ion monitoring. Volatile compounds were selected from previous studies and were compounds that were relevant to flavor or bleaching, or both (Croissant et al., 2009; Campbell et al., 2012; Jervis et al., 2012; Kang et al., 2012; Listiyani et al., 2012). Compounds were then separated and identified by GC-MS using a modified method of Liaw et al. (2010). Liquid samples were tested the day of manufacture and spray-dried powders were reconstituted at $10 \%$ solids (wt/vol) and evaluated within $7 \mathrm{~d}$. All samples contained $10 \%$ (wt/vol) sodium chloride (Fisher Scientific, Fairlawn, NJ), and $10 \mu \mathrm{L}$ of internal standard solution (2-methyl-3-heptanone in methanol at $81 \mathrm{mg} / \mathrm{kg}$; Sigma-Aldrich, Milwaukee, WI) in 20- 
$\mathrm{mL}$ autosampler vials with steel screw tops containing silicone septa faced in Teflon (MicroLiter Analytical Supplies Inc., Suwanee, GA). Samples were injected using a CombiPAL autosampler (CTC Analytics AG, Zwingen, Switzerland) attached to an Agilent 6890N GC with 5973 inert MSD (Agilent Technologies Inc., Santa Clara, CA). Samples were maintained at $5^{\circ} \mathrm{C}$ before fiber exposure. Samples were equilibrated at $40^{\circ} \mathrm{C}$ for $25 \mathrm{~min}$ before 30-min fiber exposure of a 1-cm divinylbenzene/Carboxen/polydimethylsiloxane (DVB/ CAR/PDMS) fiber (Supelco Inc., Bellefonte, PA) at 31 $\mathrm{mm}$ with 4 -s pulsed agitation at $250 \mathrm{rpm}$. Fibers were injected for $5 \mathrm{~min}$ at a depth of $50 \mathrm{~mm}$.

The GC method used an initial temperature of $40^{\circ} \mathrm{C}$ for $3 \mathrm{~min}$, which was increased at $10^{\circ} \mathrm{C} / \mathrm{min}$ to $250^{\circ} \mathrm{C}$ and then held for $5 \mathrm{~min}$. The SPME fibers were introduced into the split/splitless injector at $250^{\circ} \mathrm{C}$. A Zb-5ms column (Zb-5ms 30-m length $\times 0.25$-mm i.d. $\times$ $0.25-\mu \mathrm{m}$ film thickness; Phenomenex Inc.) was used for all analyses at a constant flow rate of $1 \mathrm{~mL} / \mathrm{min}$. Purge time was set at $1 \mathrm{~min}$. The MS transfer line was maintained at $250^{\circ} \mathrm{C}$, with the quad at $150^{\circ} \mathrm{C}$ and source at $250^{\circ} \mathrm{C}$. Compounds were identified using the NIST 2005 library of spectra (www.nist.gov) and comparison of spectra of authentic standards injected under identical conditions. Relative abundance for each compound was calculated using the calculated recovery of the internal standard concentration to determine relative concentrations of each compound. Retention indices were calculated using an alkane series (Sigma-Aldrich, Milwaukee, WI; van Den Dool and Kratz, 1963).

\section{Statistical Analysis}

All data was analyzed by a one-way ANOVA using a general linear model with the Fisher least significant difference for means separation (XLSTAT, version 2009.1.02; Addinsoft Inc., New York, NY). Replication was designated as a random effect.

\section{RESULTS}

\section{Fluid Whey and Retentate}

Composition. Compositionally, samples were not different $(P>0.05)$. Defatted fluid wheys averaged $6.71 \pm 0.05 \%$ solids, $0.89 \pm 0.05 \%$ protein, and 0.0 $\pm 0.01 \%$ fat. Retentates ( $80 \%$ protein on a dry basis) averaged $10.6 \pm 0.45 \%$ solids, $8.80 \pm 0.20 \%$ protein, and $0.67 \pm 0.05 \%$ fat. All measurements are reported on a wet-weight basis.

Norbixin and Color Analysis. Experiments were conducted to determine the optimum amount of HP needed to activate both the LP and EP systems. In fluid whey at $4^{\circ} \mathrm{C}, 10 \mathrm{mg}$ of $\mathrm{HP} / \mathrm{kg}$ provided the most bleaching in both LP and EP systems, whereas $15 \mathrm{mg}$ of $\mathrm{HP} / \mathrm{kg}$ was the most efficient in retentate for both enzymatic systems (results not shown). The optimum level of HP to activate the LP system in fluid whey at $4^{\circ} \mathrm{C}$ was very narrow $( \pm 10 \mathrm{mg} / \mathrm{kg})$, whereas those with EP added displayed a much wider range of HP addition for maximum bleaching activity (Figure 1). The same trend was observed for fluid whey at $20^{\circ} \mathrm{C}$ and $35^{\circ} \mathrm{C}$; the range for HP addition was wider for EP than LP alone (results not shown). The optimum level of HP for retentate bleaching by LP or EP was $15 \mathrm{mg} / \mathrm{kg}$. In retentate, both EP and LP alone exhibited effective bleaching ( $>80 \%$ norbixin destruction) over a wide range of HP addition $(15-250 \mathrm{mg} / \mathrm{kg})$ at either cold $\left(4^{\circ} \mathrm{C}\right)$ or warm $\left(35^{\circ} \mathrm{C}\right)$ temperatures (results not shown).

In fluid whey, bleaching with EP at 2 DBLU of MB with the addition of $10 \mathrm{mg}$ of $\mathrm{HP} / \mathrm{kg}$ for $1 \mathrm{~h}$ at $4^{\circ} \mathrm{C}$ yielded $>80 \%$ bleaching. Bleaching using only endogenous enzyme (LP) under the same conditions was slower $(P<0.05)$, requiring 6 to $24 \mathrm{~h}$ to bleach $>80 \%$ (results not shown) and variability in LP activity and optimum bleach times were observed. In fluid retentate, optimum bleach times at warm temperatures $\left(35^{\circ} \mathrm{C}\right)$ for LP and EP were not different ( 5 min, $>80 \%$ norbixin destruction; $P>0.05$; results not shown), nor were they distinct at $4^{\circ} \mathrm{C}(30 \mathrm{~min},>80 \%$ norbixin destruction; $P>0.05$; results not shown).

Descriptive Sensory Analysis. Bleached fluid wheys, regardless of bleaching treatment, had decreased sweet aromatic and cooked/milky flavors $(P<0.05$; results not shown $)$. Fluid wheys bleached using HP displayed a distinct sulfur flavor not present in enzymatically (LP or EP) bleached wheys. In retentates, similar to fluid wheys, all bleached samples, regardless of bleaching treatment, exhibited decreased sweet aromatic and cooked/milky flavors $(P<0.05)$. In addition, bleached retentates exhibited increased cardboard flavor intensities compared with control unbleached retentates $(P<0.05)$. Similar to bleaching in fluid whey, HP bleached retentate exhibited a distinct sulfur note not detected in enzymatically (either HP or LP) bleached retentates.

$\boldsymbol{G C}$ - $\boldsymbol{M S}$. Volatile compound analysis was consistent with descriptive analysis results. In fluid whey, enzymatically bleached wheys (EP or LP) were higher in aldehydes than chemically bleached wheys (HP $250 \mathrm{mg} /$ $\mathrm{kg}$; results not shown). Bleached retentates, regardless of treatment, were higher in aldehydes, including hexanal, heptanal, octanal, nonanal, and decanal, compared with unbleached controls (results not shown). In addition, retentates bleached chemically ( $250 \mathrm{mg}$ of $\mathrm{HP} / \mathrm{kg}$ ) were higher in dimethyl trisulfide than other treatments $(P<$ $0.05 ; 0.64 \pm 0.05$ vs. $0.45 \pm 0.02 \mu \mathrm{g} / \mathrm{kg})$. 


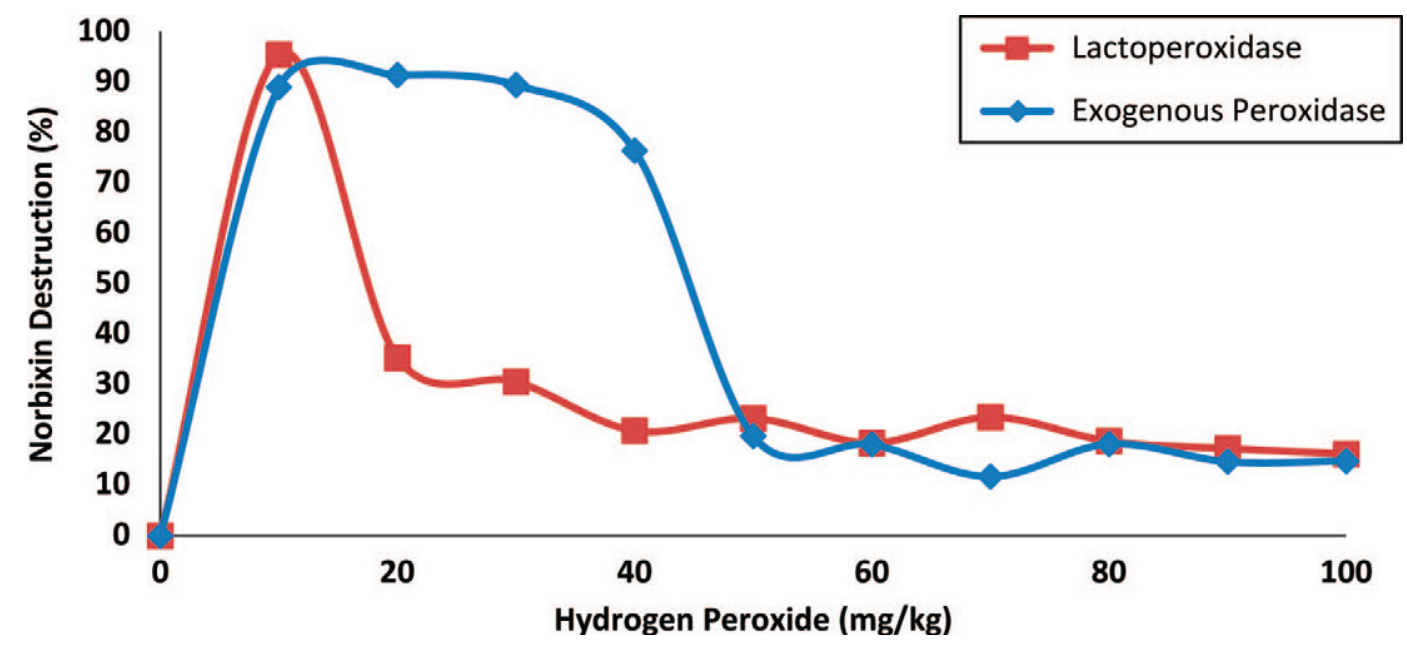

Figure 1. Bleaching efficacy of endogenous and exogenous enzymes, measured by percentage norbixin destruction, in cold fluid whey $\left(4^{\circ} \mathrm{C}\right)$ after $24 \mathrm{~h}$ at various levels of hydrogen peroxide. Lines connecting points are for visual purposes only and do not imply correlation. Color version available in the online PDF.

\section{Powder WPC80}

Composition. Compositionally, WPC80 were not different $(P>0.05)$. Powdered WPC80 averaged 96.3 $\pm 0.48 \%$ solids, $77.6 \pm 2.1 \%$ protein, and $3.7 \pm 0.4 \%$ fat on a wet-weight basis. Phosphorus, potassium, calcium, magnesium, sulfur, and sodium were not different among treatments $(P>0.05)$. Iron was the only distinct mineral; the LP WPC80 was lower in iron than the control WPC80 $(P<0.05$; Table 1$)$ and this observation has been previously documented in WPC80 from whey chemically bleached with 500 $\mathrm{mg}$ of $\mathrm{HP} / \mathrm{kg}$ (Jervis et al., 2012; Jervis and Drake, 2013).

Norbixin and Color Analysis. Consistent with and as expected from fluid whey results, enzymatic bleaching (LP and EP) removed more norbixin than traditional chemical bleaching (HP; $P<0.05$; Figure 2 ). The addition of EP increased the speed of the bleaching process, bleaching $92 \%$ in $1 \mathrm{~h}$, whereas LP and HP bleached 97 and 38\%, respectively, in $12 \mathrm{~h}$ at $4^{\circ} \mathrm{C}$. The $\mathrm{L}^{*} \mathrm{a}^{*} \mathrm{~b}^{*}$ values were consistent with norbixin values (data not shown).

Descriptive Sensory Analysis. Rehydrated WPC80 that were bleached, regardless of treatment, were characterized by a lack of sweet aromatic and buttery flavors and by increased cardboard flavor compared with the unbleached control (Table 2). Hydrogen peroxide-bleached WPC80 had a distinct oxidized/fatty flavor not detected in the other WPC80. Enzymatically bleached WPC80 with EP displayed a potato/brothy flavor but was also lower in cardboard flavor than enzymatically bleached WPC80 using LP alone (Table 2).

$\boldsymbol{G C}$ - $\boldsymbol{M S}$. Volatile analysis results were consistent with descriptive analysis results. All 4 WPC80 were distinct in their volatile profiles. Bleached WPC80, regardless of treatment, were higher in 1-octen-3-ol and 1 -octen-3-one $(P<0.05$; Table 3$)$. Among enzymatically bleached samples, LP WPC80 were higher in 2,3-octadienone, 2-pentyl furan, and hexanal than those with added EP $(P<0.05$; Table 3$)$. Heptanal was higher in EP-bleached WPC80 than the control,

Table 1. Select minerals in powdered whey protein concentrate with $80 \%$ protein (WPC80) with different bleaching treatments

\begin{tabular}{|c|c|c|c|c|c|c|c|c|}
\hline \multirow[b]{2}{*}{$\begin{array}{l}\text { Bleaching } \\
\text { treatment }^{1}\end{array}$} & \multicolumn{8}{|c|}{ Mineral concentration } \\
\hline & $\begin{array}{c}\mathrm{P} \\
\text { (\% weight) }\end{array}$ & $\begin{array}{c}\mathrm{K} \\
(\% \text { weight })\end{array}$ & $\begin{array}{c}\mathrm{Ca} \\
(\% \text { weight })\end{array}$ & $\begin{array}{c}\mathrm{Mg} \\
\text { (\% weight) }\end{array}$ & $\begin{array}{c}\mathrm{S} \\
\text { (\% weight) }\end{array}$ & $\begin{array}{c}\mathrm{Fe} \\
(\mathrm{mg} / \mathrm{kg})\end{array}$ & $\begin{array}{c}\mathrm{Na} \\
(\mathrm{mg} / \mathrm{kg})\end{array}$ & $\begin{array}{c}\text { Ash } \\
(\% \text { weight })\end{array}$ \\
\hline $\mathrm{HP}$ & $0.37^{\mathrm{a}}$ & $0.66^{\mathrm{a}}$ & $0.55^{\mathrm{a}}$ & $0.06^{\mathrm{a}}$ & $0.98^{\mathrm{a}}$ & $7.7^{\mathrm{ab}}$ & $1,900^{\mathrm{a}}$ & $3.2^{\mathrm{a}}$ \\
\hline LP & $0.37^{\mathrm{a}}$ & $0.72^{\mathrm{a}}$ & $0.53^{\mathrm{a}}$ & $0.06^{\mathrm{a}}$ & $0.94^{\mathrm{a}}$ & $7.4^{\mathrm{b}}$ & $2,200^{\mathrm{a}}$ & $3.5^{\mathrm{a}}$ \\
\hline EP & $0.38^{\mathrm{a}}$ & $0.67^{\mathrm{a}}$ & $0.56^{\mathrm{a}}$ & $0.06^{\mathrm{a}}$ & $0.96^{\mathrm{a}}$ & $8.0^{\mathrm{ab}}$ & $2,000^{\mathrm{a}}$ & $3.4^{\mathrm{a}}$ \\
\hline
\end{tabular}

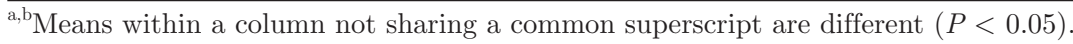

${ }^{1}$ Control $=$ no bleach; HP $=250 \mathrm{mg}$ of hydrogen peroxide $/ \mathrm{kg} ; \mathrm{LP}=$ lactoperoxidase; EP = exogenous peroxidase (MaxiBright, DSM, Delft, the Netherlands). 


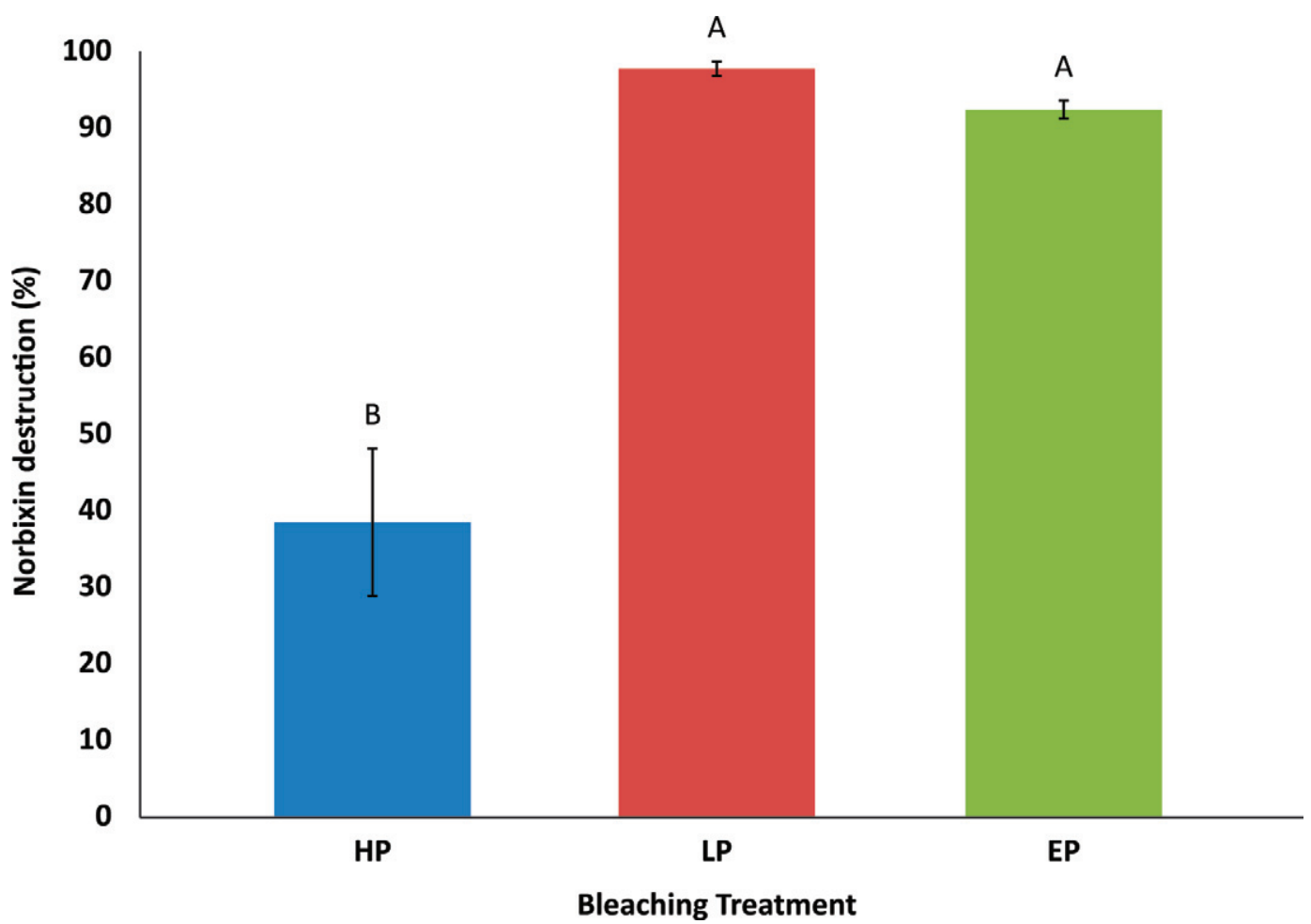

Figure 2. Bleaching efficacy, measured by percentage norbixin destruction, in powdered whey protein concentrate with $80 \%$ protein (WPC80), averaged among 3 replications. HP $=250 \mathrm{mg}$ of hydrogen peroxide $/ \mathrm{kg}$; LP = lactoperoxidase; EP = exogenous peroxidase $(2$ dairy bleaching units of MaxiBright, DSM, Delft, the Netherlands). Hydrogen peroxide and LP bleached at $4^{\circ} \mathrm{C}$ for $12 \mathrm{~h}$ and EP bleached at $4^{\circ} \mathrm{C}$ for 1 h. ${ }^{\mathrm{A}, \mathrm{B}}$ Means not sharing a common letter differ $(P<0.05)$. Color version available in the online PDF.

whereas dimethyl disulfide was higher in LP-bleached WPC80 than the control $(P<0.05$; Table 3$)$. Hexanal, a key volatile indicative of lipid oxidation, was highest in HP- and LP-treated WPC80.

\section{DISCUSSION}

Levels of HP needed to activate enzymatic systems at cold temperatures were in the range of values previ- ously reported for other temperatures (Bottomley et al., 1989; Campbell et al., 2012). In agreement with previous research, chemical bleaching using HP (250 $\mathrm{mg} / \mathrm{kg}$ ) at cold temperatures was not very effective in fluid whey but was more effective in retentate (Listiyani et al., 2012; Fox, 2013). At $4^{\circ} \mathrm{C}$, enzymatic bleaching of fluid whey was more effective than traditional chemical bleach with HP. Furthermore, the addition of

Table 2. Descriptive sensory profiles of whey protein concentrate with $80 \%$ protein $(\text { WPC } 80)^{1}$

\begin{tabular}{lcccc}
\hline & \multicolumn{4}{c}{ Bleaching treatment ${ }^{2}$} \\
\cline { 2 - 5 } Sensory attribute & Control & $\mathrm{HP}$ & $\mathrm{LP}$ & $\mathrm{EP}$ \\
\hline Aroma intensity & $2.1^{\mathrm{b}}$ & $2.5^{\mathrm{a}}$ & $2.3^{\mathrm{a}}$ & $2.4^{\mathrm{a}}$ \\
Sweet aromatic & $1.3^{\mathrm{a}}$ & $\mathrm{ND}^{3}$ & $\mathrm{ND}$ & $\mathrm{ND}^{\mathrm{a}}$ \\
Cooked/milky & $2.4^{\mathrm{a}}$ & $2.4^{\mathrm{a}}$ & $2.3^{\mathrm{a}}$ & $2.3^{\mathrm{a}}$ \\
Buttery & $0.6^{\mathrm{a}}$ & $\mathrm{ND}$ & $\mathrm{ND}$ & $\mathrm{ND}^{\mathrm{a}}$ \\
Cardboard & $1.2^{\mathrm{c}}$ & $2.5^{\mathrm{a}}$ & $2.3^{\mathrm{a}}$ & $1.9^{\mathrm{b}}$ \\
Potato/brothy & $\mathrm{ND}$ & $\mathrm{ND}$ & $\mathrm{ND}$ & $1.1^{\mathrm{a}}$ \\
Oxidized/fatty & $\mathrm{ND}$ & $1.2^{\mathrm{a}}$ & $\mathrm{ND}$ & $\mathrm{ND}^{\mathrm{ab}}$ \\
Astringent & $1.3^{\mathrm{b}}$ & $1.6^{\mathrm{a}}$ & $1.4^{\mathrm{b}}$ & $1.4^{\mathrm{ab}}$ \\
\hline
\end{tabular}

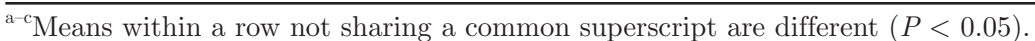

${ }^{1}$ Attribute intensities were scored on a 0- to 15-point universal intensity scale (Meilgaard et al., 2007). Most dried ingredient flavors fall between 0 and 4 (Croissant et al., 2009; Listiyani et al., 2011).

${ }^{2} \mathrm{Control}=$ no bleach; $\mathrm{HP}=250 \mathrm{mg}$ of hydrogen peroxide $/ \mathrm{kg} ; \mathrm{LP}=$ lactoperoxidase; $\mathrm{EP}=$ exogenous peroxidase (MaxiBright, DSM, Delft, the Netherlands).

${ }^{3} \mathrm{ND}=$ not detected. 
Table 3. Relative abundance $(\mu \mathrm{g} / \mathrm{kg})$ of select volatile compounds in rehydrated spray-dried whey protein concentrate with $80 \%$ protein (WPC80) with different bleaching treatments

\begin{tabular}{|c|c|c|c|c|}
\hline \multirow{2}{*}{$\begin{array}{l}\text { Volatile } \\
\text { compound }\end{array}$} & \multicolumn{4}{|c|}{ Bleaching treatment $^{1}$} \\
\hline & Control & $\mathrm{HP}$ & LP & $\mathrm{EP}$ \\
\hline 1-Hexen-3-one & $0.367^{\mathrm{b}}$ & $1.62^{\mathrm{a}}$ & $0.783^{\mathrm{b}}$ & $0.431^{\mathrm{b}}$ \\
\hline 1-Octen-3-ol & $\mathrm{ND}^{2}$ & $2.96^{\mathrm{a}}$ & $3.83^{\mathrm{a}}$ & $2.95^{\mathrm{a}}$ \\
\hline 1-Octen-3-one & ND & $2.95^{\mathrm{a}}$ & $3.01^{\mathrm{a}}$ & $1.97^{\mathrm{a}}$ \\
\hline 2,3-Octadienone & $0.213^{\mathrm{b}}$ & $0.632^{\mathrm{b}}$ & $1.507^{\mathrm{a}}$ & $0.552^{\mathrm{b}}$ \\
\hline 2-Methyl butanal & $0.199^{\mathrm{a}}$ & $0.206^{\mathrm{a}}$ & $0.211^{\mathrm{a}}$ & $0.231^{\mathrm{a}}$ \\
\hline 2-Pentyl furan & $1.467^{\mathrm{b}}$ & $3.569^{\mathrm{b}}$ & $9.385^{\mathrm{a}}$ & $3.373^{\mathrm{b}}$ \\
\hline 3-Methyl butanal & $0.044^{\mathrm{a}}$ & $0.059^{\mathrm{a}}$ & $0.079^{\mathrm{a}}$ & $0.061^{\mathrm{a}}$ \\
\hline Decanal & $0.099^{\mathrm{a}}$ & $0.115^{\mathrm{a}}$ & $0.128^{\mathrm{a}}$ & $0.083^{\mathrm{a}}$ \\
\hline Diacetyl & $0.285^{\mathrm{a}}$ & $0.249^{\mathrm{a}}$ & $0.253^{\mathrm{a}}$ & $0.246^{\mathrm{a}}$ \\
\hline Dimethyl disulfide & $0.174^{\mathrm{b}}$ & $0.705^{\mathrm{ab}}$ & $1.772^{\mathrm{a}}$ & $0.650^{\mathrm{ab}}$ \\
\hline Dimethyl sulfide & $0.643^{\mathrm{a}}$ & $0.484^{\mathrm{a}}$ & $0.498^{\mathrm{a}}$ & $0.539^{\mathrm{a}}$ \\
\hline Heptanal & $0.052^{\mathrm{b}}$ & $0.194^{\mathrm{ab}}$ & $0.456^{\mathrm{ab}}$ & $0.634^{\mathrm{a}}$ \\
\hline Hexanal & $1.59^{\mathrm{b}}$ & $7.69^{\mathrm{a}}$ & $5.98^{\mathrm{a}}$ & $3.54 \mathrm{~b}$ \\
\hline Nonanal & $0.533^{\mathrm{a}}$ & $0.569^{\mathrm{a}}$ & $0.492^{\mathrm{a}}$ & $0.331^{\mathrm{a}}$ \\
\hline Octanal & $0.555^{\mathrm{a}}$ & $0.604^{\mathrm{a}}$ & $0.565^{\mathrm{a}}$ & $0.451^{\mathrm{a}}$ \\
\hline$p$-Xylene & $0.294^{\mathrm{ab}}$ & $0.401^{\mathrm{a}}$ & $0.187^{\mathrm{b}}$ & $0.187^{\mathrm{b}}$ \\
\hline Toluene & $2.91^{\mathrm{a}}$ & $2.65^{\mathrm{a}}$ & $2.99^{\mathrm{a}}$ & $2.49^{\mathrm{a}}$ \\
\hline
\end{tabular}

${ }^{\mathrm{a}, \mathrm{b}}$ Means within a column not sharing a common superscript are different $(P<0.05)$.

${ }^{1}$ Control $=$ no bleach; HP $=250 \mathrm{mg}$ of hydrogen peroxide $/ \mathrm{kg}$; LP = lactoperoxidase; $\mathrm{EP}=$ exogenous peroxidase (2 dairy bleaching units of MaxiBright).

${ }^{2} \mathrm{ND}=$ not detected

EP in fluid whey increased the speed of bleaching at $4^{\circ} \mathrm{C}$. In an industrial setting, dosing the correct amount of HP for enzymatic bleaching into a continuous fluid whey system can be difficult to do precisely. Seasonal variations and processing deviations may also occur that alter the amount of HP needed to activate the LP system, further complicating matters. As such, it is may be beneficial in industrial settings to add EP to increase the speed of bleaching as well as robustness of the bleaching system.

In retentate, the addition of $\mathrm{EP}$ did not increase the speed of enzymatic bleaching $(P>0.05)$ but in fluid whey, the addition of EP greatly increased the speed of bleaching $(P<0.05$; EP: $1 \mathrm{~h}, \mathrm{LP}: 12 \mathrm{~h})$. The decreased effect of the exogenous enzyme in retentate is likely because native LP is concentrated along with protein during UF and is present at much higher levels in retentate than in fluid whey. As such, enzymatic activity is increased and the speed of bleaching in retentate increases compared with fluid whey. Similar to fluid whey, the LP system in retentate can be permanently inactivated if too much HP is dosed into the system. Fox (2013) demonstrated that in liquid whey protein retentate, $250 \mathrm{mg}$ of $\mathrm{HP} / \mathrm{kg}$ destroyed more norbixin than $500 \mathrm{mg}$ of $\mathrm{HP} / \mathrm{kg}$, suggesting that the LP range for HP is much higher in retentate (up to $250 \mathrm{mg} / \mathrm{kg}$ ) than in fluid whey (up to $20 \mathrm{mg} / \mathrm{kg}$ ), which is also consistent with results from the current study. Increases in enzyme levels, whether from membrane filtration or the addition of EP, increase the range at which HP can be dosed without permanently inactivating LP.
As expected, bleached fluid wheys and retentates, regardless of bleaching treatment, had decreased sweet aromatic and cooked/milky flavors and increased cardboard flavor $(P<0.05)$. Increased cardboard flavor as a result of lipid oxidation in fluid whey, 34 and $80 \%$ protein retentate, and 34 and $80 \%$ protein spray-dried powders have been extensively documented (Croissant et al., 2009; Campbell et al., 2011, 2012; Listiyani et al., 2011, 2012; Jervis et al., 2012; Kang et al., 2012). Fluid wheys and retentates that were chemically bleached with HP contained a distinct sulfur flavor not present in enzymatically (LP or MB) bleached wheys ( $P$ $<0.05$; results not shown). Increased volatile sulfur compounds and distinct sulfur flavor in chemically HP bleached WPC80 have been previously reported (Jervis et al., 2012) and higher concentrations of dimethyl trisulfide were documented in fluid retentates that were bleached with HP in the current study. Previous studies have also demonstrated functional differences between HP-bleached whey protein and unbleached controls, suggesting that HP affects protein integrity (Jervis et al., 2012; Campbell et al., 2013). Volatile sulfur compounds are formed from protein degradation of sulfur-containing amino acids (Wright et al., 2006). Although it does not directly influence cardboard flavor, hexanal is considered a good indicator of lipid oxidation and cardboard flavors (Whitson et al., 2010). Hexanal relative abundance was higher in LP- and HP-bleached samples than unbleached or EP-bleached WPC80. Higher relative abundance of this lipid oxidation compound is consistent with sensory results that 
LP- and HP-bleached WPC80 were higher in cardboard flavor than unbleached or EP-bleached WPC80.

The WPC80 from fluid whey bleached using EP exhibited a distinct potato/brothy flavor. Potato flavor can be caused by a wide array of volatile compounds, but is mainly attributed to methional, an aroma compound formed from the degradation of the amino acid methionine (Jansky, 2010). Methional was not detected by headspace volatile compound analysis in EP WPC80, even though a distinct potato flavor was detected by trained sensory panelists. The threshold for methional is very low (less than $5 \mu \mathrm{g} / \mathrm{kg}$; KaragülYüceer et al., 2004). It is possible that methional was below instrumental headspace detection but still readily detected by trained panelists. It is also possible that another compound is responsible for the potato flavor in EP WPC80 documented by trained panelists. Methional has been detected previously by gas chromatography-olfactometry and by solvent extraction with GC-MS, but not by SPME GC-MS in dried whey protein concentrates, isolates, and hydrolysates (Carunchia Whetstine et al., 2005; Leksrisompong et al., 2010). Additional studies on the flavor chemistry of EP WPC80 would be required to confirm the source of this flavor.

\section{CONCLUSIONS}

It is imperative that dried dairy ingredients be colorless and bland in flavor to increase ingredient applications. Bleaching is required to eliminate color, but also produces undesirable flavors that can carry through into the finished product and influence consumer acceptance. Alternative bleaching agents, such as EP, can bleach effectively and can eliminate more color than traditional chemical bleaching agents in less time. These results demonstrate that off-flavors due to lipid oxidation are still present in enzymatically bleached WPC80 but are the same or lower in intensity than HP-chemically bleached WPC80 and lower in lipid oxidation volatiles that HP-chemically bleached WPC80. By bleaching at cold temperatures, manufacturers can minimize off-flavors and decrease membrane fouling. The addition of exogenous enzyme increased the speed of bleaching at $4^{\circ} \mathrm{C}$ in fluid whey and also the range of HP allowed for enzymatic bleaching in fluid whey. As such, EP may be beneficial in an industrial setting where continuous dosing of a narrow range of $\mathrm{HP}$ is difficult.

\section{ACKNOWLEDGMENTS}

Funding was provided in part by the Dairy Research Institute [DRI; formerly Dairy Management Inc. (DMI),
Rosemont, IL] and by DSM (Delft, the Netherlands). The advice and assistance of Eric Bastian (Glanbia, Twin Falls, ID) and Ilco Boogers (DSM, Delft, the Netherlands) is gratefully acknowledged. The use of trade names does not imply endorsement or lack of endorsement of those not mentioned.

\section{REFERENCES}

AOAC International. 2000. Official Methods of Analysis. 17th ed. AOAC International, Gaithersburg, MD.

Bottomley, R. C., R. D. Colvin, and M. Van Blanton, inventors. 1989. Decolorising of whey and whey products derived from whey. Express Foods Group Ltd. (Middlesex, GB2), assignee. US Pat. No. $4,888,184$.

Campbell, R. E., M. C. Adams, M. A. Drake, and D. M. Barbano. 2013. Effect of bleaching permeate from microfiltered skim milk in 80\% serum protein concentrate. J. Dairy Sci. 96:1387-1400.

Campbell, R. E., E. J. Kang, E. Bastian, and M. A. Drake. 2012. The use of lactoperoxidase for the bleaching of fluid whey. J. Dairy Sci. 95:2882-2890.

Campbell, R. E., R. E. Miracle, and M. A. Drake. 2011. The impact of starter culture and annatto on the flavor and functionality of whey protein concentrate. J. Dairy Sci. 94:1185-1193.

Carunchia Whetstine, M. E., A. E. Croissant, and M. A. Drake. 2005. Characterization of dried whey protein concentrate and isolate flavor. J. Dairy Sci. 88:3826-3839.

Croissant, A. E., E. J. Kang, R. E. Campbell, E. Bastian, and M. A. Drake. 2009. The effect of bleaching agent on the flavor of liquid whey and whey protein concentrate. J. Dairy Sci. 92:5917-5927.

Drake, M. A., Y. Karagul-Yuceer, K. R. Cadwallader, G. V. Civille, and P. S. Tong. 2003. Determination of the sensory attributes of dried milk powders and dairy ingredients. J. Sens. Stud. 18:199216.

Drake, M. A., R. E. Miracle, and J. M. Wright. 2009. Sensory properties of dairy proteins. Pages 429-448 in Milk Proteins: From Expression to Food. A. Thompson, M. Boland, and H. Singh ed. Elsevier. New York, NY.

Fox, A. J. 2013. The influence of bleaching agent and temperature on bleaching efficacy and norbixin interactions with whey components. MS Thesis. North Carolina State University, Raleigh.

Jansky, S. H. 2010. Potato flavor. Am. J. Potato Res. 87:209-217.

Jervis, S., R. E. Campbell, K. L. Wojciehowski, M. A. Drake, and D. M. Barbano. 2012. Impact of bleaching whey on sensory and functional properties of $80 \%$ whey protein concentrate. J. Dairy Sci. 95:2848-2862.

Jervis, S. M., and M. Drake. 2013. The impact of iron on the bleaching efficacy of hydrogen peroxide in liquid whey systems. J. Food Sci. 78:R129-R137.

Kang, E. J., R. E. Campbell, E. Bastian, and M. A. Drake. 2010. Invited review: Annatto and bleaching in dairy foods. J. Dairy Sci. 93:3891-3901.

Kang, E. J., T. J. Smith, and M. A. Drake. 2012. Alternative bleaching methods for Cheddar cheese whey. J. Food Sci. 77:C818-C823.

Karagül-Yüceer, Y., M. A. Drake, and K. R. Cadwallader. 2004. Evaluation of the character impact odorants in skim milk powder by sensory studies of model mixtures. J. Sens. Stud. 19:1-13.

Kussendrager, K. D., and A. C. M. van Hooijdonk. 2000. Lactoperoxidase: Physico-chemical properties, occurrence, mechanism of action and applications. Br. J. Nutr. 84(Suppl. 1):S19-S25.

Leksrisompong, P. P., R. E. Miracle, and M. A. Drake. 2010. Characterization of flavor of whey protein hydrolysates. J. Agric. Food Chem. 58:6318-6327.

Liaw, I. W., H. Eshpari, P. S. Tong, and M. A. Drake. 2010. The impact of antioxidant addition on flavor of Cheddar and Mozzarella whey and Cheddar whey protein concentrate. J. Food Sci 75:C559-C569.

Listiyani, M. A. D., R. E. Campbell, R. E. Miracle, D. M. Barbano, P. D. Gerard, and M. A. Drake. 2012. Impact of fat separation, 
temperature, and bleaching agent on bleaching of liquid Cheddar whey. J. Dairy Sci. 95:36-49.

Listiyani, M. A. D., R. E. Campbell, R. E. Miracle, L. O. Dean, and M. A. Drake. 2011. Influence of bleaching on flavor of $34 \%$ whey protein concentrate and residual benzoic acid concentration in dried whey proteins. J. Dairy Sci. 94:4347-4359.

Lloyd, M. A., S. J. Hess, and M. A. Drake. 2009. Effect of nitrogen flushing and storage temperature on flavor and shelf-life of whole milk powder. J. Dairy Sci. 92:2409-2422.

Meilgaard, M. C., G. V. Civille, and B. T. Carr. 2007. The Spectrum ${ }^{\mathrm{TM}}$ descriptive analysis method. Pages 189-253 in Sensory Evaluation Techniques. CRC Press, Boca Raton, FL.

Mercadante, A. Z. 2008. Food colorants: Chemical and functional properties. Pages 447-478 in Analysis of carotenoids. C. Socaciu, ed. CRC Press, Boca Raton, FL.

Pühse, M., R. T. Szweda, Y. Ma, C. Jeworrek, R. Winter, and H. Zorn. 2009. Marasmius scorodonius extracellular dimeric peroxidase - Exploring its temperature and pressure stability. Biochim. Biophys. Acta 1794:1091-1098.

Reiter, B., and B. G. Harnulv. 1982. The preservation of refrigerated and uncooled milk by its natural lactoperoxidase system. Dairy Industries Int. 47:13-19.
Scheibner, M., B. Hülsdau, K. Zelena, M. Nimtz, L. de Boer, R. G. Berger, and H. Zorn. 2008. Novel peroxidases of Marasmius scorodonius degrade $\beta$-carotene. Appl. Microb. Biotechnol. 77:12411250 .

Seifu, E., E. M. Buys, and E. F. Donkin. 2005. Significance of the lactoperoxidase system in the dairy industry and its potential applications: A review. Trends Food Sci. Technol. 16:137-154.

van Den Dool, H., and P. D. Kratz. 1963. A generalization of retention index system including linear temperature programmed gas-liquid partition chromatography. J. Chromatogr. A 11:463-467.

Whitson, M. E., R. E. Miracle, and M. A. Drake. 2010. Sensory characterization of chemical components responsible for cardboard flavor in whey protein. J. Sens. Stud. 25:616-636.

Wright, J. M., M. E. Carunchia Whetstine, R. E. Miracle, and M. Drake. 2006. Characterization of cabbage off-flavor in whey protein isolate. J. Food Sci. 71:C86-C90.

Zelena, K., H. Zorn, M. Nimtz, and R. G. Berger. 2009. Heterologous expression of the msp2 gene from Marasmius scorodonius. Arch. Microbiol. 191:397-402.

Zorn, H., S. Langhoff, M. Scheibner, and R. G. Berger. 2003. Cleavage of $\beta, \beta$-carotene to flavor compounds by fungi. Appl. Microbiol. Biotechnol. 62:331-336. 